\title{
PARADOX OF BUREAUCRACY NEUTRALITY IN THE INDOENSIA REGIONAL ELECTION
}

\author{
Sukri Tamma \\ Institute of Southeast Asian Studies, Faculty of Philosophy, Bonn University \\ Nasserstrase 2, Bonn 53113, Germany \\ E-mail: s5susukr@uni-bonn.de
}

\begin{abstract}
This paper aims provides how the actual issue of neutrality of Indonesian bureaucracy, especially on the Civil Servants of local government related to the Local election process. The important position of civil servants as public servants with its network touches many aspects of community life makes people as dependent on the bureaucracy existence. At the same time, bureaucracy seems under the politicians' interests due to their position in the system of regional government. This study also simultaneously shows how the concept of neutrality implements in Indonesian bureaucracy associated with the Indonesian political system, including in the context of the regional government.
\end{abstract}

Keywords: Bureaucracy, Neutrality, Regional Government, Civil Servant, Regional Election.

\begin{abstract}
Abstrak
Artikel ini mencoba memberikan gambaran tentang bagaimana sikap netral dari birokrasi di Indonesia khusunya terutama para pegawai negeri sipil daerah terkait dengan proses pemilihan umum lokal. Posisi penting PNS sebagai pelayan masyarakat dengan jaringan menyentuh yang dapat menyentuh segala aspek kehidupan masyarakat, membuat masyarakat tergantung pada keberadaan birokrasi tersebut. Pada waktu yang sama, birokrasi tampakberada di bawah kepentingan para politisi karena posisi mereka dalam sistem pemerintahan daerah. Artikel ini juga secara simultan menunjukkan bagaimana konsep netralitas diterapkan dalam birokrasi di Indonesia terkait dengan sistem politik di Indonesia termasuk dalam hal ini adalah pemerintah daerah.
\end{abstract}

Kata Kunci,: Birokrasi, Netralitas, Pemerintah Daerah, Pegawai Negeri Sipil, Pemilihan Daerah.

\section{INTRODUCTION}

Bureaucracy is one of the most important organizations in the world today. Bureaucracy plays a crucial role in the system of modern society. As an organization that has activities associated with variation of government implementation policy, they are occupying a fundamental position not only in term of the political system and government, but also in the existing social system. Bureaucracy is the embodiment of the state in providing services to the various aspects of people. The important role of the bureaucracy affect their existence makes them as an appropriate institution that located between the obligation to serve people and adherence to the system and its 


\section{6 | Sukri Tamma}

institutional structure. Therefore, the issue of how to put bureaucracy more neutral between both aspects is an important issue, including in Indonesia.

In Indonesia, the embodiment of bureaucracy is associated with state institutions in a structure of government existence. The civil servants or "pegawai negeri sipil" (PNS) or today called the State Civil Officers (ASN) is regarded as the embodiment of bureaucracy which play pivotal role in the community system of living. It makes contradictory and dillematic of bureaucratic position between as a political tool of a certain political power, including the rulers or as the public administrator that should focus on the professionalism and efficiency of public services were not affected by political interests including in changes of the government leadership. Hence the question of the importance neutrality for bureaucracy becomes a crucial thing in analysis Indonesian bureaucracy related to existing political system, including in the Indonesian election process.

Today, issue of bureaucracy neutrality this case the civil servants has become an important thing in context the regional area especially in term of regional elections. In that process to vote for the regional government head, bureaucratic position, then asked to be neutral institutionalized. The bureaucracy potentiality to influence voters on a particular candidate as well as desire of candidates to win the election, then meet in the paradoxal where forces important of neutrality. Politicians have the potentiality to utilize the bureaucracy network for their interests in the political arena when that is possible for bureaucrats involve in that arena at least to achieve a higher position or simply to keep this position in the regional government structures. That is becoming inclination which emphasizes important issues of neutrality and the various implications related to the bureacracy position.

\section{METHODS}

This paper uses the Weberian and Marxian perspective analysis in the position of the bureaucracy as part of the Indonesian political system. Both perspectives are used primarily as the analysis method in studies of bureaucracy, especially in relation to issues concerning the position of bureaucracy in Indonesia political system dynamic and its function as a public servant. By uses these two perspectives it pointed a assessment standard of the bureaucracy neutrality issue in Indonesia. Moreover, both perspective possible to provide an alternative form of neutrality that possibly as blend those or even totally different.

Thus, this paper is based on the literature studies related to the neutrality of bureaucracy position theme. This analysis puts on the assumption that this perspective has used at the same time. This is in line with that proposed by Miller and Yang (2008) that the main similar or 
different main perspectives, but analyze same thing will always have a point of commonality as well as differences in the analysis and the result of analysis. $^{1}$

\section{CONCEPT OF BUREAUCRACY AND ITS POSITION IN POLITICALSYSTEM}

Nowadays, bureaucracy is a very important organization in the system of modern society. As a system of organization works, the bureaucracy has a long history of its existence primarily associated with the history of the development of life and civilization in Europe and Asia thousands of years ago $^{2}$. Along with the development of society and social context has produce diversity concepts and descriptions associated with the bureaucracy. This condition is also strongly associated with the diversity of perspectives that are used in explaining the phenomenon of bureaucracy existence.

Basically, the word "bureaucracy" is derived from the word "bureau", which was used from the beginning of the 18th century in Western Europe to refer the office, ie, workplace, where the officials worked. In French language, the word is defined as "baize" which means the cover of the table. The term bureaucracy came into use near before the French Revolution in 1789 which later spread to many more countries. Ideally, bureaucracy characterized by hierarchical authority relationships, defined the subject competence ball impersonal rules, recruitment by competence, and has fixed income. ${ }^{3}$

The term "bureaucracy" was actually introduced by a French philosopher namely Vincent de Gourmay in 1765, but since it introduction bureaucracy has tended to attach with a negative connotation. It seems as a contradiction of the term "laissez faire" which also introduce to build image of freedom of action and efficiency. In this context the term "bureaucracy" is associated with the routine, associated with behavior and inefficiency. ${ }^{4}$

In its development, concept of bureaucracy later described by Max Weber in the sociological perspective to interpret as "rational efficient organisation". Historically, Max Weber saw the importance of bureaucracy as part of the system of people's lives. Weber describes bureaucracy as another form of organization that has technical advantage and have complexity in the

1 Gerald J. Miller and Kaifeng Yang, eds., Handbook of Research Methods in Public Administration, Second Edition, 2 edition (Boca Raton: CRC Press, 2007).

2 Peter M. Blau and Marshall W. Meyer, Bureaucracy in Modern Society, 2nd edition (New York: Random House USA Inc, 1988).

3 Asuman Altay, "The Efficiency of Bureaucracy on the Public Sector," Dokuz Eylül Üniversitesi Íktisadi ve Ídari Bilimler Fakültesi Dergisi 14, no. 2 (May 16, 2013), http://dergi.iibf.deu.edu.tr/index.php/cilt1-sayi1/article/view/64.

${ }^{4}$ O. Tierean and G.Bratucu, "The Evolution of the Concept of Bureaucracy," Bulletin of the Transilvania University of Brasov 2, no. 51 (2009): 245-50. 


\section{8 | Sukri Tamma}

syste. ${ }^{5}$ In Weber's views, characteristics of bureaucratic organization are Hierarchy where each staff has a clear competence in a hierarchical division of labor and the assessment is based on the performance shown; Continuity, a permanent staff with regular salary based on certain standards and career atges always offered on a regular basis; Impersonality, the work is based on a merit system (profesionality) trained by function, and control of access to knowledge or information file. ${ }^{6}$

That Weber's characteristics showed a general explanation of how bureaucratic institutions should be designed, including the importance of labor division, personnel career with specialized training and expertise, hierarchical formal organizational structure that does not duplicate other administrative unit, explicit rules and procedures to ensure the clear lines of authority and accountability in the organization. ${ }^{7}$

That condition shows that bureaucracy is governed through rational principles. Offices are ranked in a hierarchical order and their operations were marked by impersonal rules. Well established to regulate by methodical allocation of jurisdictions and the bounded task. Certainty structures made for special qualifications than ascriptive criteria. That is because bureaucratic system and coordination usually due to a large number of people as modern forms of organization.

Furthermore, Martin Albrow defines bureaucracy in seven categories which are; Rational organization, Organizational efficiency, Rule by Officials, public administration, administration by Officials, ether the public or private sectors, an organizational form Characterized by such qualities as hierarchy and rules, and an essential quality of modern society. ${ }^{8}$ That definition shows that bureaucracy is the administrative structure and the regulations in place to control (rationalize and make in effective and professionalism) activities. It is generally found in large organizations and government organizations. ${ }^{9}$

Similar to Albrow, tried to show that the characteristics of bureaucracy are: a hierarchical structure, which also has authority delegation from the top to the bottom of the organization; a series of official positions have certain duties and responsibilities; a set of formal rules, regulations and standards of the organization's operations and behavior of its members; employ staff who

\footnotetext{
${ }^{5}$ Altay, "The Efficiency of Bureaucracy on the Public Sector," 45.

${ }^{6}$ David Beetham, Bureaucracy (Milton Keynes: Open University Press, 1987).

${ }^{7}$ George Krause and Kenneth J. Meier, eds., Politics, Policy, and Organizations: Frontiers in the Scientific Study of Bureaucracy (Ann Arbor: University of Michigan Press, 2005).

${ }^{8}$ Martin Albrow, Bureaucracy (London: Palgrave Macmillan, 1970).

${ }_{9}$ Blau and Meyer, Bureaucracy in Modern Society.
} 
are qualified on the basis of career development with promotion based on qualifications and performance. ${ }^{10}$

Various definitions are then made bureaucrats or people who work in a bureaucratic organization can identify as who is working in a large organization; accept money as payment for his work with the organization that is one of the largest sources of revenues; hired, promoted and retained based on their performance; produce a result that cannot be evaluated by the market can be called as a bureaucrat. ${ }^{11}$

Facts that bureaucrats is employed full-time showed that they really intended to focus on their work. Moreover, every element in the bureaucracy, including the staff has clear responsibilities and objectives of each process works. Therefore, a system of promotion based on ability and achievement that can be achieved by any staff based on the duties and responsibilities and not for other reasons such as gender, social background, race and so forth. The promotion system is showing bureaucracy should be separated from "depersonalizes" condition. Therefore, every matter relating to personal feelings and irrational should be kept away from the bureaucracy existence. It will make bureaucrats will always professionally works based on the tasks and achievements of the organization that sets trough some regulations.

In contrast to Weber's idea of professional bureaucracy, Karl Marx precisely expressed thoughts about alienation bureaucracy. Marx did not agree with Weber, who stating that alienation is only a transitional stage on the road to true human emancipation. At this point Marx tends to see that bureaucracy cannot be professional as Weber stated. For Marx and some Marxists thinkers, the bureaucracy cannot be separated from the context of conflict of class which is a necessity in the history of mankind.

The Marxist thinkers have focused mainly on aspects of the employment relationship conflict, and the consequences for the structure and functioning of the organization. The Marxist studies of the organization, thus contrast to the traditional functionalist, organic conception and community organizations and experts who blur the fundamental differences of interests that make up the organization. In Marxist perspectives of bureaucracy, it will relate through conflict due to the exploitation of certain classes against another. $^{12}$

10 Donald P. Warwick, A Theory of Public Bureaucracy: Politics, Personality, and Organization in the State Department (Place of publication not identified: Harvard University Press, 1979).

11 Anthony Downs, "A Theory of Bureaucracy" (unpublised paper, November 1964), https://www.rand.org/content/dam/rand/pubs/papers/2008/P3031.pdf.

12 Paul S. Adler, ed., The Oxford Handbook of Sociology and Organization Studies: Classical Foundations, Reprint edition (Oxford; New York: Oxford University Press, 2010). 
Thus, due to exploitation and conflict is important within Marxist perspective, control, then becomes fundamental and foremost in this perspective to the organization's observations included in a bureaucratic organization. The Marxist thought asserts that the issue of control in an organization usually arises in any collective effort because the control is part of an effort to exploit included in the interests of capitalist exploitation. ${ }^{13}$

Another thing that exists in the Marxian perspective is the effect on employees of bureaucratic organization and the way they viewed the work and duties. Individuals who become as bureaucrats have a different preference structure, that would affect to difficulty in policy making and coordination. Implications to associating bureaucratic with individual or personality aspects will chaotic and affect made some distortion to the channels of communication within the organization. ${ }^{14}$ In order to avoid confusion between individuals within the bureaucracy, then only regulations as aspects that can control it. It is usually manifested in a set of standard procedures that dictate the execution of all processes within the institution, division of power, hierarchy and relationships. ${ }^{15}$

In terms of function, bureaucracy plays two important functions. Administrative functions efforts were made to study the implementation of scientific and bureaucratic processes. The political function focus is on designing government agencies, namely, creating the institutions that will formulate, adopt and implement policies. The latter is inherently determined. ${ }^{16}$

According to Weber, the power of modern bureaucracy can be incredible though it tends to be ambivalent. On the one hand, it sees modern bureaucracy as the only rational and thus ultimately desirable form of organization. On the other hand, especially in the later works, he declared doubts about the influence of modern public administration. Therefore, in an attempt to carry out their duties efficiently and to control the people, a strict separation of the political and administrative realms become indispensable by bureaucratic. ${ }^{17}$

13 Ibid., 74.

${ }^{14}$ Anthony Downs, "A Theory of Bureaucracy," 2.

15 O. Tierean and G.Bratucu, "The Evolution of the Concept of Bureaucracy."

16 Krause and Meier, Politics, Policy, and Organizations, 2.

17 Fritz Sager and Christian Rosser, "Weber, Wilson, and Hegel: Theories of Modern Bureaucracy," Public Administration Review 69, no. 6 (November 2009): 1136-47, doi:10.1111/j.1540-6210.2009.02071.x. 
Based on those exposures, there are two major perspectives associated with the bureaucracy Weberian and Marxian. Weberian bureaucracy ideally sees that their work is professional in accordance with the duties and responsibilities outlined by the state regulations as well and apart from the influence of politics. In this case Weberian perspective saw the importance of the neutrality of the various influences outside the system works is governed by formal regulations. While the Marxian view that the bureaucracy is part of the construction of class contention. Thus the bureaucracy is likely to become part of the domination of one class is like having authority and power. Therefore, the neutrality of the bureaucracy as imagined by Weberian perspective can not be found in the Marxian perspective.

\section{INDONESIAON BUREAUCRACY NETRALITY}

In simple, neutrality can be interpreted as not taking part in a party or a conflicting. Within its development as a concept, neutrality has obtained legal definition and acceptance, and have adapted to the system of people's lives, so it develops in understanding. It makes the way and context of how neutrality defined is important. ${ }^{18}$

According to the Indonesian Dictionary "neutrality" is meant an impartial, neutral or did not participate or does not help either party. So Neutrality became a state and free attitude of a certain partiality. During the term of modern lives where there are many interest from various parties, neutrality becomes part of important issue within the mankind dynamics. Therefore, nowadays, neutrality also became one of issues in the context of a state or government existence.

In the context of the state, a form of neutrality associated with the constitution or in the form of an agreement. Definition of neutrality and differences between different labels indicating that it is part issue in modern lives. At this point, codification of neutrality associated with the emergence of the state were in the modern context, neutrality tend to be associated with a state-centric concept. However, this concept has basically been there and precedes existence of a sovereign state where actually neutrality have been observed in the lives of ancient peoples. ${ }^{19}$

In terms of state, people may use "state" in discussions neutrality principle to be applied strictly, especially related with people's lives are governed constitutionally. It tends associated with the basic principles of government general structure and political process: the legislative, executive

${ }^{18}$ C. Agius and K. Devine, “'Neutrality: A Really Dead Concept?' A Reprise," Cooperation and Conflict 46, no. 3 (September 1, 2011): 265-84, doi:10.1177/0010836711416955.

19 Ibid., 269. 
and judicial branches; the scope of majority rule and people. In this meaning, there are basic rights and freedoms are equal citizenship, which must be respected such as the right to vote and to participate in politics, freedom of conscience, freedom of thought and association, as well as the protection of the rule of law. ${ }^{20}$ In that context, existence of bureaucracy as part of the state should be in a position to run a constitution without favoring certain circles in the society. The fact that system of government, political participation, freedom of thought and behavior are very diverse people then make bureaucracy always faced to different behaviors and different desires. However, due to the constitution, which is neutral in regulating these matters, the bureaucracy should also be neutral. Huge influence on the essence of constitution existence means that there should be no one is discriminated based the constitution. It then interpreted as a good constitution, therefore the constitution must be neutral. ${ }^{21}$

Indeed, the constitution and its implementor are neutral, but the principle of neutrality does not mean that the constitution prohibits people to do something according to their capacity. ${ }^{22}$ Admittedly, neutrality seems difficult to do in all aspects of life. But the existence of a constitution is fundamental becoming as standard of neutrality in maintaining neutral stance countries including the bureaucracy. Neutrality is believed to promote the establishment of the country's goal to bring a better life. It shows that in the context of a country where bureaucracy becomes an important part, neutrality can be attributed to the purpose, justification, or effects. ${ }^{23}$

In the context of the Indonesian government, the cornerstone of importance of bureaucracy neutrality or in this case the civil servants (PNS) have also become a very important issue. As the policy implements, the civil servant position becomes very crucial related to the community lives. Importance of neutrality in Indonesian bureaucracy, even becomes a fundamental part of the bureaucratic reform scenario. Its goal is to stabilize professional bureaucracy which means a neutral bureaucracy from political interest of politicians. If previously (in the new order era) civil servants was part of certain political group control where they were directed to support openly the ruling regime, but today the civil servants formally asked to be neutral where the bureaucracy does not ask to support certain political

${ }^{20}$ John Rawls, Political Liberalism, Expanded ed, Columbia Classics in Philosophy (New York: Columbia University Press, 2005).

21 Ian Jennings, Against State Neutrality Raz, Rawls, and Philosophical Perfectionism (Saarbrücken: Südwestdeutscher Verlag für Hochschulschriften, 2011), http://nbnresolving.de/urn:nbn:de:101:1-20111022533.

22 Ibid., 24.

23 Ibid., 45. 
group directly. It's actually as the concept of neutrality of Indonesian bureaucracy.

Moreover, Miftah Thoha, stating that the neutrality of bureaucracy is essentially a system in which the bureaucracy will not change in providing services to anyone who became ruler of the government. ${ }^{24}$ Thus, civil servants will continue to carry out its duties and functions despite a shift in the government's leadership. At this point, the neutrality is more attached to the regulation and the existing constitution. Formally, under Article 2 part $f$ in the Act No. 5 year 2014 concerning the State Civil Apparatus (ASN), It realized that neutrality is part of the basis for the implementation of government in Indonesia. It shows the government is well aware of the importance of neutrality of the Indonesian bureaucracy. Thus, it comes with the inclusion of principle of professionalism on the part $b$ of this article. It provides that government makes both of those as part of the dynamic presence of bureaucracy or the civil servants. In article 4 section d deeply confirmed that ASN conduct their duties professionally and impartially.

Furthermore, as a form of implementation that law, the government sets a more detailed formal foundation of neutrality implementation in Indonesian bureaucracy. It is determined by the Government Regulation No. 37 years 2004 on the inside contained a prohibition for civil servants to become a member of political parties. This regulation shows government's desire to hides civil servants from the influence of the political interests of the various parties to prohibit a member of a political party. It is expected that they will not affect either in the process of promotion and in carrying out his duties from the interests of certain political parties.

Formally the government tried to show that development of bureaucracy associated with neutrality seems as something mandatory and political parties into organizations considered unacceptable because it concern will bring negative effects including the neutral attitude with them. Therefore, violation of this prohibition will lead to civil servants get strict sanctions ranging from a mild to the possibility of being fired as a civil servant.

In order to affirms an Indonesian government's desire to positioned neutral bureaucrats, the principle of neutrality, then linked to the elections in Indonesia. Thus, the principle of neutrality implemented also in the upcoming general elections, both Presidential Election, Member of the House of Representatives and the Regional Representative Council and Regional Head Election. In related to the general election, the government even made several changes in government regulation until today thru the Government

\footnotetext{
${ }^{24}$ Miftah Thoha, Birokrasi Dan Politik Di Indonesia (Jakarta: Raja Grafindo Persada, 2003).
} 
Regulation No. 49 years 2008. This condition seems an ideal thing to ensure that civil servants will not be affected by some aspects of the election that possibly disrupts their neutrality. Yet it is precisely at this point there is a paradox in the election. That paradox lies precisely in desire to reposition the civil servants is neutral in the political dynamics, but at the same time they still be given the right to vote. The condition seems strongly associated with the inclusion of clauses relating to human rights (HAM) in the 1945 amendment, which is the Indonesian constitution.

In the some articles of the Constitution, it contains some Human Rights (HAM chapters relating to political rights. Among them is the article 28C paragraph (2) which states that "everyone has the right to advance himself in fighting for their rights collectively to build a society, nation and country".

Furthermore, Article 28D paragraph (3) states that every citizen has the right to obtain equal opportunities in government and in article 28E (3) shows that every person is entitled to freedom of association, assembly and expression. Those statements actually show that the state guarantees the freedom of every citizen to express their political rights. As part of the Indonesian citizen, the civil servants are also part of those whose basically protected by the state, including in their involvement in elections as candidates and as voters. As a moderate way of encouragement position of the PNS in neutral position and free from political influence while still have rights to vote, the civil servants are allowed to vote even to be a candidate but under some circumstances.

In the context of the regional Election, due to importance to maintain the neutrality of bureaucracy, the Government issued a Government Regulation No. 53 Year 2010. In article 4 point 15 states that each civil servant are prohibited from "providing support to prospective Regional Head / Deputy Head of Region, by: a) engaging in campaign activities in support candidates for Regional Head / Deputy Head of Region; b) use the facilities associated with a position in the campaign activities; c) make decisions and / or actions that favor or disfavor one candidate during the campaign period; and / or d) conduct activities that lead to bias against candidates who participated in the elections before, during, and after the campaign includes meetings, solicitation, appeal, or the provision of goods to civil servants in the work environment, family members, and community".

Thus, the neutrality of civil servants in the elections, actually does not lead to the disappearance of political rights either to run as candidates or to vote. The neutrality of the civil servants is more likely to limited involvement of bureaucracy in socializing or campaigning particular candidate or political party. It's intended to make civil servants can still separates his position as a civil servant who has an important position as an officer of the state 
administration. Due to their serves various forms of community needs in association with certain parties in an election or regional election, which will enable it to influence or even suppress the public more to follow directions or offense support for the opposing party to support or her choice, civil servants should put its neutrality properly. By neutrality as stipulated in the existing regulations, the civil servants strived to does not take advantage from its position to mobilize support for certain parties. It will be interpreted as the non-neutrality of civil servants in the election and the election because it is considered a potential to benefit certain parties.

\section{PARTIALITY IN THE NEUTRALITY OF BUREAUCRACY IN REGIONAL ELECTION}

In the context of the regional election, the neutrality of bureaucracy or civil servant is always important. After the first period of simultaneously Election in 2015, then menyusl election, then will continue to the second phase in 2017, this issue has always been important in the dynamics of democratic proses in Indonesia. Since Indonesia entered the reform era that is characterized by some fundamental changes in the social-political structures in Indonesia, the issue of bureaucracy neutrality in the election, even never stops and always present in every electoral process in every region. The issue seems very relevant to the paradoxical position in view of bureaucracy in Indonesia itself.

As provided before, the understanding of bureaucracy neutrality in election process basically does not is eliminate their political rights to vote or to be voted. Based on the various regulations their position in the election process, the neutrality of civil servants is basically a form of government efforts so that they are not involved in the conflict between political interests to participate in the process of socialization and mass mobilization unless bureaucrats are chosen to be one of the Candidates which thus has chosen to lose its status as a civil servant based on the existing regulation. The problems actually arise on the voting rights owned by civil servants. It is because as a civil servant, their position is not lost when they use their voting rights. Position as a civil servant and the use of suffrage is that basically raises contradictively and vulnerability for civil servants to be not neutral.

When the state still gave right to vote for the civil servants regulated thru formal laws, basically it gives way the civil servants to be as the nonneutral bureaucrat. If the civil servant ultimately uses their rights to vote, it means they will support one candidate and ignore the other candidate meant they will as partial bureaucrats. But due to the laws allows these conditions, to vote shall not be considered as non-neutrality. It is strongly associated 
with neutrality rules that associate with exclusion of civil servants to come to socialize and mobilize mass support for a particular candidate that they support.

Formally, it looks easy to implement. However, various cases that arise with violations that occur in various regional elections in various regions of Indonesia show how difficult neutrality be implemented ideally. It seems relevant to the conditions surrounding the bureaucrats that drives the partiality of bureaucracy become phenomenon that always found in every regional election event in Indonesia, including in the Indonesia reform era. There are many factors possibly comes as the reason for partiality of the bureaucrats in the regional election. These reasons tend to be associated with idealistic, economic, or emotional closeness. Those reasons are leading to potential collisions of interest that seems to be known and have even been planned by civil servants themselves. Apart from the civil servants themselves, a condition that causes bureaucracy to be part in the election process came from the position of the head of the region itself that will be voted within the regional election.

In terms of civil servants, which allow a bureaucrat is partial or involved in to introduce or mobilize masses for a particular candidate is an important position and great authority possessed by the head of the region as head of government. As the head of the regional government, they have direct control and influence to the existence of civil servants in the bureaucratic structures as stipulated in Law No. 23 Year 2014 on the Regional Government.

In the article 65 of the Law Number 23 Year 2014 concerning the duties and authority of the regional head as well as article 66 on the role and authority of the deputy head of the region, the formal laws demonstrated the magnitude of the power and authority of the regional head of the workings of the local government system. This includes the implementation of the functions and responsibilities of each institution that exist in local government. It makes the regional head and its deputy has a crucial position to control bureaucratic system, including to determines people in that system. Thru their formal authority, the regional head has authority to appoint people who wanted to able to occupy a particular position of existing in the system of regional government.

As part of implementing the provisions of Article 232 paragraph (1) of Law Number 23 Year 2014 on Regional Government, on June 15, 2016 the government has issued Government Regulation No. 18 year 2016 about the regional structures of government. The regulation explained that Region is an element of the head of the Region and the Regional Representatives Council in the implementation of Government Affairs under the authority of the 
Regions. The regional institutions are part of the regional government system. It meant that the organizations which become part of the system of civil servants working on it a regional chief aide. It certainly created conditions in which every civil servant has a formal obligation to work under the command of the region head where the civil servants should obey the leadership.

Basically, a formal obedience to leaders for every civil servant is placed in formal structures are arranged in formal regulations. Thus the oblation of the bureaucracy out the regional leader is not based on preference or personal proximity to Country leader, but was based on a rule-based professional. Thus, formally the possibility for civil servants becomes a tool of personal interests outside the regional head professional values will be unavoidable. However, these conditions is not easy for civil servants. Awareness of civil servants that position and increase their career as PNS are very dependent on their leaders, then the civil servants tend to lay into obedience and compliance is not only because the standard of professionalism, but also for their hope and concerns about the sustainability of their careers as civil servants in the head region.

Facts that promotion and demotion of civil servants will be associated with the condition of their economic well-being, then a civil servant then be in a situation to continue to ensure that the leadership still had the good judgment to them. Thus, in addition to making efforts through the work of professional, another possibility to get the attention of the leadership is when civil servants are identified as supporters of the head region. Therefore, there is a tendency among civil servants to show their support to the regional head not only in professional intention but also personally.

In the personal context, the proximity of a civil servant at the head of the region can be a way for civil servants get a better opportunity for development their career, at least it will have good access to the center of power in the region. Thru that access, a civil servant who has close relation to the regional head personally will allow for promotion to positions of importance in the structure of local government bureaucracy. As a logical consequence of a better position, then a civil servant has the opportunity to benefit not only in economic reasons but also socially. In the context of a society, civil servants are still considered as respectable position, then the positions held within local government structures will make civil servants got some social benefits.

At the regional head sides, the position of the bureaucratic organization made up of staff of civil servants in local government system is basically a mobilization potential of the votes to win the election process. The total civil servants quantitatively under the control of regional heads and their support 
potential associated with a kinship network that has made civil servants as a potential barn will very interesting. In addition, the social position and influence in the community for various functions implemented related to the various needs of the community, making them also as an opportunity to drum up support from community mobilization. Therefore, in the process regional election, the bureaucracy has always been a target for the candidates. In this condition, the civil servants potentially to see the regional election as a vehicle for opportunity to gain better career and position where at the same time access to important power centers in the area. Therefore, the involvement of civil servants in the election process even occurs long before the voting process.

Within the days of the campaign is a means to provide support to the specific regional head candidate to be used as a handle for them to realize the course. Through the support of a candidate, the civil servants involved would hope that if the latter was elected head of the area they will have a positive impact. At the very least, they will not put in a low level position that do not reflect or even do not have potential economic benefits. Furthermore, thru the importance of electing for their existence as a civil servant, not rare even among civil servants dares to make sacrifices both financially and by risking its current positions. This condition is basically indicating a strong correlation between the election of a candidate supported by the positions held are usually closely related. The condition is basically indicating a strong tendency for the formation of a pattern of the patron - client relationship between civil servants with politicians who become candidates in the election arena.

Muller noticed that the clientelistic relationships in various types of bureaucracy is not only seen on how the bureaucracy controlled by politicians to distribute conditional resources in exchange for electoral support. ${ }^{25}$ In that context, the phenomenon of partiality of bureaucracy at the time they are required to remain neutral in the election process should also be viewed in the context of how the bureaucratic institutions and regional head position is important in the structure of local government in influencing the distribution of important resources that exist in the area. As a result, patterns of patronage relationships formed by the non-neutrality of civil servants in the election to form groups allow bureaucracy in the structures of local government be more people who have access and opportunity to occupy important positions that have socioeconomic status. At the same time

25 Wolfgang C. Müller, "Political Institutions and Linkage Strategies," in Patrons, Clients, and Policies, ed. Herbert Kitschelt and Steven I. Wilkinson (Cambridge: Cambridge University Press, 2007), 251-75, http://ebooks.cambridge.org/ref/id/CB09780511585869A020. 
it will have the potentiality to inhibit the opportunity for other civil servants who also has a formal opportunity to compete professionally in accessing key positions in organizations in the sphere of local government.

For the politicians, including the regional head, it will still be ahead in the competition next term election as the incumbent, to build relationships in the form of patronage is a common strategy and maintained properly. The relationships allow them to control the civil servants who are in various local government institutions to coincide with the position of the head area as well as other matters related to the potential gain in the allocation of resources.

That condition indicates neutrality of bureaucracy in Indonesia basically is aligned. Although expected to be neutral, but civil servants still have the right to vote that allows them to support or even participate in the process to socialize a candidate. Thus, the neutrality of the bureaucracy seems to tend only as an attempt to avoid civil servants from the diversity of the political interests of politicians, but some conditions surrounds the civil servants and the desire of politicians to reach a position of regional head makes bureaucracy will difficult to truly neutral in the election.

In fact, there is a tendency that the election process was an opportunity for civil servants, not only for those who target positions at a high level and important in the structure of local bureaucracy because it has been formally qualified to get a promotion if the head of the region is pleased to promote it. The interesting of regional election due to be an opportunity for civil servants, although not yet eligible to be promoted in high positions, but they still have the opportunity to access positions at the level corresponding to their rank level.

That condition makes the election tend to like betting arena for civil servants. By choosing to be not neutral is by participating in the campaign for the election of a particular candidate to the public, a civil servant is basically being gambled by breaking the rules of neutrality. It shows an awareness of civil servants ready to receive some sanction according to the rules for their violation. Moreover, fundamentally they also risked position and sustainability of their careers. If the candidate they support wins the election, then for five years the civil servants will enjoy an advantageous position and access to power. However, if the candidate they support loses, then they would be prepared to not have a chance or even excluded from the opportunity to access some important positions in the regional government bureaucracy structures.

That condition actually shows that although Indonesia tries to promote a bureaucratic system that is neutral in terms of professional and free from the influence of private or political interests based on the perspective of Weberian, but in practice, the various regulations and conditions that exist 
around the civil service and the bureaucratic apparatus of local government showed a tendency of Marxian. It shows the civil servants basically can not really be neutral in the sense of impartiality. Their desire to gain access to the regional government authority as well as opportunities for promotion on various important positions to make a lot of civil servants choosing to stake their position even must violate the rules. The condition seems to be well understood by the candidate who wants to reach the position as head of the region. Seeing the potential of the bureaucracy through the civil servants to mobilize support of the politicians always trying to have the support of the civil servants course with some of the promises about the opportunity to reach a certain position and the potential to improve the socioeconomic status in the system of local governance.

\section{SUMMARY}

Neutrality in the bureaucracy in Indonesia is basically not a true neutrality that is completely impartial and free from political influence of the dynamics that take place around it. In the context of the regional election, although there are a series of regulations governing neutrality of bureaucracy, but the fact remains that civil servants have the right to vote makes them difficult to fully impartially. Neutrality is only limited to a ban on civil servants to be involved in the campaign or mobilize mass support for a particular candidate.

A fact that thru some regulations on local government, regional head position is very important and very influential in the structure of local government bureaucracy makes this position to be one of the main determinants of promotion and transfer policies of the bureaucrats in the area. Thus, any civil servants who want to get promotions at certain positions who have social implications economy necessarily have to go through the approval of the regional head. It makes civil servants tend to attempt to gain the trust of the head of the region through approaches, including nonprofessionals such as providing personal support. The condition was met with interest of the politicians who are interested to become the regional head who thru the next period election to mobilize the potential of the support of as many people who become voters. The number of civil servants as well as the powers and duties they have become a fundamental attraction for each candidate to be able to use it.

Thus the election basically has become the arena for the local bureaucrats and candidates for mutual advantage in reaching their respective interests. It is confirmed that Indonesia is not a figures the Weberian professional bureaucracy. Facts of various elections in Indonesia demonstrate that inclination bureaucracy in Indonesia is closer to the 
Marxian perspective where bureaucracy became part of the political dynamics and power struggles within the local government. The tendency of the formation of patronage relationships between regional heads of the politicians who wins the power and authority of the bureaucracy is a strong indicator of neutrality is partial in the bureaucracy in Indonesia.

\section{REFERENCES}

Adler, Paul S., ed. The Oxford Handbook of Sociology and Organization Studies: Classical Foundations. Reprint edition. Oxford; New York: Oxford University Press, 2010.

Agius, C., and K. Devine. "'Neutrality: A Really Dead Concept?' A Reprise." Cooperation and Conflict 46, no. 3 (September 1, 2011): 265-84. doi:10.1177/0010836711416955.

Albrow, Martin. Bureaucracy. London: Palgrave Macmillan, 1970.

Altay, Asuman. "The Efficiency of Bureaucracy on the Public Sector." Dokuz Eylül Üniversitesi İktisadi ve İdari Bilimler Fakültesi Dergisi 14, no. 2 (May 16, 2013). http://dergi.iibf.deu.edu.tr/index.php/cilt1sayi1/article/view/64.

Anthony Downs. "A Theory of Bureaucracy." unpublised paper, November 1964.

https://www.rand.org/content/dam/rand/pubs/papers/2008/P3031. pdf.

Beetham, David. Bureaucracy. Milton Keynes: Open University Press, 1987.

Blau, Peter M., and Marshall W. Meyer. Bureaucracy in Modern Society. 2nd edition. New York: Random House USA Inc, 1988.

Jennings, Ian. Against State Neutrality Raz, Rawls, and Philosophical Perfectionism. Saarbrücken: Südwestdeutscher Verlag für Hochschulschriften, 2011. http://nbn-resolving.de/urn:nbn:de:101:120111022533.

Krause, George, and Kenneth J. Meier, eds. Politics, Policy, and Organizations: Frontiers in the Scientific Study of Bureaucracy. Ann Arbor: University of Michigan Press, 2005.

Miftah Thoha. Birokrasi Dan Politik Di Indonesia. Jakarta: Raja Grafindo Persada, 2003.

Miller, Gerald J., and Kaifeng Yang, eds. Handbook of Research Methods in Public Administration, Second Edition. 2 edition. Boca Raton: CRC Press, 2007.

Müller, Wolfgang C. "Political Institutions and Linkage Strategies.” In Patrons, Clients, and Policies, edited by Herbert Kitschelt and Steven I. Wilkinson, 251-75. Cambridge: Cambridge University Press, 2007. http://ebooks.cambridge.org/ref/id/CB09780511585869A020.

O. Tierean, and G.Bratucu. "The Evolution of the Concept of Bureaucracy." Bulletin of the Transilvania University of Brasov 2, no. 51 (2009): 24550 . 
Rawls, John. Political Liberalism. Expanded ed. Columbia Classics in Philosophy. New York: Columbia University Press, 2005.

Sager, Fritz, and Christian Rosser. "Weber, Wilson, and Hegel: Theories of Modern Bureaucracy." Public Administration Review 69, no. 6 (November 2009): 1136-47. doi:10.1111/j.1540-6210.2009.02071.x.

Warwick, Donald P. A Theory of Public Bureaucracy: Politics, Personality, and Organization in the State Department. Place of publication not identified: Harvard University Press, 1979.

Received 27 Oktober 2016, Revised 24 Desember 2016, Accepted 26 Desember 2016, Available online xx-xxxx-2016 